\title{
The Human Vaccines Project: A roadmap for cancer vaccine development
}

Pedro Romero ${ }^{1}$, Jacques Banchereau ${ }^{2}$, Nina Bhardwaj ${ }^{3}$, Mark Cockett ${ }^{4}$, Nora Disis ${ }^{5}$, Glenn Dranoff $^{6}$, Eli Gilboa ${ }^{7}$, Scott A Hammond ${ }^{8}$, Robert Hershberg ${ }^{9}$, Alan J. Korman ${ }^{10}$, Pia Kvistborg ${ }^{11}$, Cornelis Melief ${ }^{12}$, Ira Mellman ${ }^{13}$, A. Karolina Palucka ${ }^{2}$, Irina Redchenko ${ }^{14}$, Harlan Robbins ${ }^{15}$, Federica Sallusto ${ }^{16}$, Theodore Schenkelberg ${ }^{17}$, Stephen Schoenberger ${ }^{18}$, Jeffrey Sosman ${ }^{19}$, Özlem Türeci ${ }^{20}$, Benoît van den Eynde ${ }^{21}$, Wayne Koff ${ }^{22}$ and George Coukos ${ }^{1}$

${ }^{1}$ Ludwig Cancer Research at University of Lausanne, 1066 Epalinges, Switzerland, ${ }^{2}$ The Jackson Laboratory for Genomic Medicine, Farmington, CT 06032, USA, ${ }^{3}$ cahn School of Medicine at Mount Sinai, New York, NY, 10029 USA, ${ }^{4}$ Bristol-Myers Squibb, Wallingford, CT06492, USA, ${ }^{5}$ University of Washington School of Medicine, Seattle, WA 98109-4714, USA, , ${ }^{6}$ Novartis Institutes for Biomedical Research, Cambridge, MA 02139, USA, ${ }^{7}$ Sylvester Comprehensive Cancer Center, Miami, FL 33136, USA, ${ }^{8}$ Medlmmune, Way Gaithersburg, MD 20878, USA, ${ }^{9}$ Celgene Immuno-Oncology Center of Excellence, Seatlle, WA 98102, ${ }^{10}$ BristolMyers Squibb, Biologics Discovery California, Redwood City, CA, $94063{ }^{11}$ Netherlands Cancer Institute, 1066CX, Amsterdam, The Netherlands, ${ }^{12}$ ISA Pharmaceuticals \& Leiden University Medical Center, 2333 ZA Leiden, ${ }^{13}$ Genentech, San Francisco, CA 94080, USA, ${ }^{14}$ Oxford University, Oxford, OX3 7DQ, UK, ${ }^{15}$ Adaptive Biotechnologies, Seattle, WA 98102, USA, ${ }^{16}$ IRB, 6500 Bellinzona, Switzerland, ${ }^{17}$ West Monument Consulting, 1906 R Street NW St. 11, Washington DC 20009, USA, ${ }^{18}$ La Jolla, San Diego, CA 92037, USA, ${ }^{19}$ Vanderbilt University Medical Center and Vanderbilt Ingram Cancer Center, Nashville, TN 37232 , USA, ${ }^{20} \mathrm{Cl} 3$ Cluster for Individualized Immunotherapy, Kupferbergterasse 17-19, 55131 Mainz, Germany, ${ }^{21}$ Ludwig Institute for Cancer Research, Brussels branch, Brussels, BRU 1200, Belgium, ${ }^{22}$ International AIDS Vaccines Initiative, 125 Broad Street, 9th Floor, New York, NY 10004, USA

Corresponding Author: George Coukos, MD, PhD

Email: george.coukos@chuv.ch / Telephone: +4121314 0627 


\begin{abstract}
Cancer vaccine development has been vigorously pursued for 40 years. Immunity to tumor antigens can be elicited by most vaccines tested, but their clinical efficacy remains modest. We argue that a concerted international effort is necessary to understand the human anti-tumor immune response and achieve clinically effective cancer vaccines.
\end{abstract}

The benefits of effective vaccines for human health and the economy have been demonstrated time and time again. Vaccines have the potential to conquer not only acute infectious disease but also chronic infections and cancer. However, despite numerous clinical studies of a large number of cancer vaccine formulations in thousands of cancer patients, therapeutic cancer vaccination has had only modest effects with a low rate (less than $7 \%$ ) of objective clinical responses (1) and an overall rate of clinical benefit of around 20\% (2-6). Many reasons have been invoked to explain the lack of clinical efficacy observed with many therapeutic cancer vaccines (7). Most tumor antigens that have been used for vaccination are non-mutated self antigens, for which a tolerized $T$ cell repertoire offers mostly $T$ cells with low affinity $T$ cell receptors (TCR) unable to mediate effective anti-tumor responses. In contrast, viral antigens and mutation-based neoantigens, which are not subject to thymic tolerance, are the preferred target antigens for therapeutic vaccines (7). Moreover, many vaccines have relied on monovalent antigen-targeting strategies that may select resistant tumor variants. In addition, the delivery systems used have been largely suboptimal, resulting in generally weak and shortlived antigen-specific $T$ cell responses. All of this is compounded by the immunosuppressive tumor microenvironment. The latter has been dramatically highlighted by the clinical success of immune checkpoint blockade with monoclonal antibodies against CTLA-4 and PD-1/PD-L1 (8). Treatment with these blocking antibodies is revolutionizing the management of advanced metastatic cancer and resulted in FDA approvals of three new treatments for melanoma, lung, and renal cancer in a record time. The search for predictive biomarkers is ongoing and focused on the observation that clinical responders usually bear tumors that are heavily infiltrated by $T$ cells, show signs of IFN- $\gamma$ activity, and often express a high load of neoantigens. In a preclinical mouse model, therapeutic vaccination against neoantigens had the same efficacy as anti-CTLA4 or PD-1 checkpoint blockade $(9,10)$. Thus, there is now renewed interest in pursuing the development of cancer vaccines through achieving effective immunomodulation. This would likely include identifying pharmacological interventions that correct microenvironment barriers $(11,12)$, mining the vast repertoire of tumor neoantigens (13), and the harnessing of systems vaccinology/immunology tools (14).

\title{
The Human Vaccines Project
}

The recent advances in large-scale genomics and proteomics provide the means to define the "normal" immune system and to obtain highly detailed models of system-wide perturbations taking place during immune reactions. The current technology and state of knowledge in systems biology, computational biology, structural biology, and immune system monitoring should make it possible to develop effective vaccines and immunotherapies in the foreseeable future. The idea of launching an international Human Vaccines Project (the Project) as a 
platform to attain this goal was proposed about two years ago (15). The initial scientific framework was formulated by a group of experts gathered last year (16), subsequently followed by a series of programmatic workshops to help define pilot studies to be implemented beginning in 2016. In addition, a workshop was held with key officers of pharmaceutical companies and the academic and government sectors to develop a business model for organization of the consortium (17).

The Project has been established as a non-for-profit public-private partnership whose mission is to accelerate the development of vaccines and immunotherapies against major global infectious diseases and cancers by decoding the human immune system. The Project's major objectives include: 1) Deciphering of the human immunome, comprising both the naïve and the adaptive repertoires in heterogeneous populations, and relatedly, the human antigenome representing the targets of the immune system on infected and neoplastic cells; 2) elucidating the principles or "rules" of immunogenicity, such as how to elicit durable and clinically effective immune responses; and identifying vaccination strategies generating and sustaining effector $\mathrm{T}$ cell responses in the context of large and persistent antigen burdens. Together, achievement of these scientific objectives at unprecedented scale over the next decade could usher in a new era of global disease prevention and control. Currently, the Project is nearing completion of its catalytic stage, developing the core network of pharmaceutical companies, academic research centers, clinical trial sites, immune monitoring laboratories and a bioinformatics/data management center, and plans to embark on its initial set of pilot studies later this year.

Here we discuss tumor antigens and their prioritization, antigen delivery, immune system fitness, induction of long-lived immune memory, and strategies for the next decade of international collaborative cancer vaccine development. Finally, we outline a consensus for a roadmap to cancer vaccine development within the Project and lay out the planned activities for its first year.

\section{Tumor antigens}

Early cancer vaccines used irradiated whole tumor cells as carriers of the entire collection of tumor antigens, letting the patient's immune system sort out the relevant ones. A review of 173 published peer-reviewed immunotherapy trials that used either a single molecularly defined synthetic antigen or whole tumor in patients with different solid tumor types found a much higher rate of objective clinical responses in 1711 patients who received whole tumor relative to 1733 patients who received molecularly defined tumor antigens (18). However, randomized phase III trials testing allogeneic lysate vaccines failed to demonstrate clinical efficacy. In fact, concerns regarding increased mortality in the vaccination arm were raised in one randomized trial (19, 20). However, a phase III randomized study with autologous renal tumor cell vaccine in 379 evaluable patients with stage pT2-3b pN0-3 M0 renal-cell carcinoma after radical nephrectomy showed a higher rate of progression-free survival at 5 years in patients who received adjuvant vaccination (21), suggesting that unique antigens (mutation-based neoantigens) expressed in autologous tumor lysate preparations may be important determinants of effective vaccination. The complexities in collection and formulation of autologous whole tumor vaccines have limited 
the expansion of this approach in the clinic and have created an impetus for the development of molecularly defined vaccines.

The first T cell-defined human tumor antigen was identified in 1991 by molecular cloning of the gene encoding MAGE-A1 (22), and numerous tumor antigens have been identified since then with this approach (23) or by screening with autoantibody repertoires of cancer patients (24). Therapeutic vaccination attempts built on these targets have been largely disappointing to date, indicating that vaccine monotherapy based on these antigens is clinically inefficient. Possible reasons include not only immune evasion upon selection of antigen loss variants but also weak vaccine formulations and a limited, low-avidity and tolerized T cell repertoire that is deployed in an immunsuppressive tumor environment. Today, massive parallel DNA/RNA sequencing combined with advanced computational methods enable the high throughput identification of all prevalent non-synonymous mutations in a tumor sample, the so-called mutanome, and provides the basis for antigen discovery focusing on the identification of $T$ cell epitopes containing somatically mutated residues, referred to as mutant neoantigens (13). These, like the foreign antigens expressed on virus-induced cancers (7), are expected not to be subject to central immunological tolerance, and therefore vaccination may elicit high affinity/avidity CTLs with increased efficacy relative to historic vaccines directed to self-cancer antigens. The association of high mutational load with greater responses to immune checkpoint blockade in metastatic melanoma and lung cancer $(25,26)$ and with increased T cell infiltrates in a variety of solid tumors (27) has provided further validation of the possible relevance of tumor neoantigens. In pre-clinical models (10), mutant neoantigens can generate robust CD8 T cell responses and provide efficient therapeutic vaccination. With the plethora of tumor antigen choices emerging, future clinical studies should address the question of how to identify antigens for vaccine development to elicit the most robust immune-mediated clinical response.

\section{Antigen prioritization}

Initial prioritization of tumor antigens for vaccination considered the available evidence of their expression, relative antigenicity, and immunogenicity (table 1) (28), but it preceded the recent revolution in cancer immunotherapy and did not consider the possibilities presented by the use of mutant neoantigens. Thus, it is time to revisit tumor antigen prioritization, taking into account recent advances in the field. Informed prioritization of tumor antigen candidates for vaccine development should consider the degree of relatedness to self-antigens. With such a metric, virally encoded antigens and neoantigens would be at the top of the list. Frequently mutated sequences in some tumors (such as the EGFR vlll isoform in glioma) would also represent important targets for vaccination strategies. However, the uniqueness of the repertoire of mutations in every patient's tumor has spurred personalized approaches informed by NGSbased identification of each patient's mutanome. In this approach, the somatic mutations giving rise to peptides that are processed and bind to any of the $\mathrm{MHC}$ class I or class II allelic products in the patient need to be identified through a bioinformatic pipeline. The fraction of somatic mutations yielding an epitope in any individual patient is low. Moreover, the fraction of the population expected to present even a recurring mutation is a function of the frequency of the presenting MHC allele, which is generally low. Personalized neoantigen-targeted trials using either mutant RNA or mutant peptides as antigens are recruiting melanoma patients 
(NCT02035956, NCT01970358). One trial involving three metastatic melanoma patients has recently reported promising results (29). Post-translationally modified peptides and MAGE-type antigens, lineage and differentiation antigens in non-vital tissues, and overexpressed antigens should follow. Occasionally, specific self-antigen epitopes also escape from central thymic tolerance induction and can therefore be considered as effective vaccine ingredients $(30,31)$.

A systematic analysis of relevant antigens through next generation sequencing in samples from patients with documented clinical benefit from immune checkpoint blockade therapy or responding to vaccination with unbiased antigen preparations such as tumor lysates, mRNA, or whole tumor cell vaccines could provide additional avenues for antigen prioritization. In addition, there is emerging scientific rationale for the design of assays to screen for the existence of central tolerance in the thymus (32) to aid in antigen prioritization (33).

\section{Antigen delivery}

Antigen delivery is the cornerstone of vaccination. Numerous antigen delivery platforms are available to date, and many of these have been tested in clinical trials of cancer patients. They can be grouped into vectored or biochemically defined antigen formulations. The latter may be peptide/protein-based or nucleic acid-based. A broad definition of vector delivery systems would include inert ones such as polymeric supports, microbial-based ones, and mammalian cell vectors such as autologous dendritic cells.

a) Vectored vaccines

Tumor vaccines have been developed using a large variety of viral, bacterial, and even fungal/mycobacterial vectors, taking advantage of ample experience in the field of vaccines against infectious pathogens. Viral vectors such as pox and adenovirus are ideally suited to induce robust CD8 T cell responses. Several cancer vaccines based on vaccinia or other pox viruses have been tested in advanced phase clinical trials. For example, Prostvac is based on two recombinant pox viruses carrying prostate-specific antigen (PSA) along with genes encoding costimulatory molecules (34). Some bacterial vectors produce selective inducers of strong CD8 T cell responses, and a human papillomavirus vaccine with the E7 gene expressed in Listeria monocytogenes has reached advanced clinical testing in women with advanced cervical carcinoma (35). Listeria vaccines expressing mesothelin are also being tested in pancreatic cancer (NCT00585845). A general drawback with microbial vectors is their strong immunogenicity resulting from their non-self nature and the high number of antigens carried by the numerous gene products that are still preserved in the vectors. In addition, the rapid induction of neutralizing antibodies may preempt boosting and makes it necessary to identify appropriate heterologous prime-boost regimens. An interesting approach is to use oncolytic viruses injected into accessible tumor lesions. The ensuing tumor cell lysis provides a source of antigens, including neoantigens. A Herpes simplex 1 virus with reduced virulence and transgenic expression of GM-CSF might provide an efficient means of "endogenous" or in situ vaccination (36).

Inert vectors based on polymeric particles are also promising players in cancer vaccine development. Synthetic materials may be shaped into nanoparticles of various sizes ranging 
from a few nanometers to micrometer level or contained in wafers with various degrees of porosity (37). The antigen cargo can be delivered and released into specific tissues at rates that can be controlled by the chemical formulations (37). In addition, the surfaces of particles can be decorated with various ligands that may engage costimulatory receptors on $T$ cells or scavenger receptors on professional antigen presenting cells, or additional chemical moieties that may avoid systemic phagocytosis or specifically target tumors or secondary lymphoid organs, thus allowing accurate localization for immune response activation. Additional immune modulators might be embedded in such vehicles such as cytokines, immunomodulatory antibodies, or Tolllike receptor (TLR) agonists. A special type of nanoparticles are those assembled by recombinant viral capsid subunits that self-assemble into viral-like particles. These are particularly well-suited for antibody response induction and have found enormous success in prophylactic vaccines such as the HPV L1 vaccines (38). However, they also have strong intrinsic immunogenicity, similar to their parental viruses.

Dendritic cells (DC) have been extensively tested in cancer vaccination. The rationale for this is the recognition of their ability to induce de novo adaptive immune responses. However, their exceedingly low numbers in blood and tissues, the diversity of functional specialization of different DC subtypes, and the inefficiency with which injected DCs home to lymphoid organs make this approach still challenging and as yet, not particularly efficacious. Nevertheless, targeting endogenous DCs is an attractive strategy for vaccine design, and several targets have already been validated in pre-clinical studies (39-41).

b) Biochemically defined vaccine formulations

Peptides and proteins are straightforward antigen delivery formulations amply tested in clinical trials of cancer vaccination. Short, exact length class I MHC-binding peptides efficiently elicit specific CD8 T cells only if properly delivered with potent adjuvants. A combination of oil emulsion together with a TLR9 agonist is a potent inducer of specific CD8 T cells (42). TLR9 and TLR3 agonists work best at inducing a favorable CD8 to regulatory $T$ cell ratio and tumor control in experimental models (43). In contrast, slow release of short peptide alone efficiently induces regulatory $\mathrm{T}$ cell expansion (44). Long synthetic peptides may be superior to short peptide immunogens in at least two ways: they induce broader $T$ cell responses including antigen-specific CD4 T cells, and they minimize the chances of tolerance induction because of the need for antigen processing by dendritic cells. In addition, long peptides are processed for presentation by both $\mathrm{MHC}$ class I and class II molecules much more effectively than proteins (45). Both p53 and HPV-16 E6 and E7 long synthetic peptide cocktails induce specific antitumor immunity in cancer patients $(46,47)$.

Proteins purified from recombinant expression vector cultures have been also tested in the clinical arena. The MAGE-A3 and NY-ESO-1 proteins are polypeptides of a few hundred amino acids expressed by variable proportions of tumors of different histotypes. Unfortunately, the clinical signals detected in randomized phase II clinical trials of vaccination with the MAGE-A3 protein could not be reproduced in phase III trials, resulting in the abandonment of this vaccine development program (http://us.gsk.com/en-us/media/press-releases/2014/update-on-phase-iiiclinical-trial-of-investigational-mage-a3-antigen-specific-cancer-immunotherapeutic-in-non- 
small-cell-lung-cancer/). A hurdle for proteins as cancer vaccines is the inefficient induction of specific CD8 T cells by immunization with the current formulations, though this may be improved by next generation adjuvants. This may be caused by the nearly exclusive processing of these proteins in the endocytic compartment resulting in predominant specific CD4 T cell responses. The need for efficient means of diverting proteins to the cross-priming pathway in specialized dendritic cells has been recognized and more research is needed to find practical ways of achieving this through vaccination (48).

Nucleic acids are attractive delivery vehicles. Extensive testing in humans and animal models highlights the value of DNA vaccines to prime T cell responses that are then boosted by other antigen delivery methods such as proteins or live recombinant vectors. Although historically DNA vaccines have elicited weak responses, the use of electroporation and chimeric constructs comprised of highly immunogenic sequences of pathogens may drive potent CD8 responses $(49,50)$. A recent study showed that DNA vaccines expressing HPV oncoproteins have the capacity to clear localized cancer (51). Antigen-encoding mRNAs provide another way to transiently deliver antigen. Rational modifications of these molecules enable their stabilization inside the cells, with the consequent increased time for translation and gene expression of the antigen. Signals can be added to the vector to direct the translated protein products into either the cytosolic or the endocytic cell compartments, to elicit CD8 or CD4 biased T cell responses, respectively (52). This format offers the possibility of using multiple mRNAs for polyantigen vaccines or preparing arrays of minigenes encoding multiple target epitopes, both class I and class II MHC-restricted (53). An important issue when designing vaccines with multiple epitopes is antigen competition for presentation. This is particularly acute with microbial vectors which carry a multitude of foreign antigens that may readily prime high affinity $T$ cells. Heterologous prime boost regimens using peptides or nucleic acid-based vaccines for priming and separation of antigens delivered for priming may allow overcoming the antigen competition hurdle.

\section{$T$ cell memory in cancer vaccines}

A major goal of cancer vaccines is the induction of long-lived memory $T$ cell responses that continue to regenerate the effector $T$ cells required to eliminate tumor cells and to suppress tumor reactivation long-term.

The current models of memory $T$ cell formation involve specific transcriptional programs, with high T-bet and Blimp-1 and low Eomes and BCL6 associated with an effector differentiation, and a low T-bet/Eomes ratio characteristic of memory T cell differentiation(54). FOXO1 represses T-bet expression and promotes Eomes-mediated building of proliferative potential (55) as well as other transcription factors such as Tcf7. Blimp-1 and BCL6 have opposing effects, as do ID2 and ID3 (54). Thus, a delicate balance of transcription factor expression underlies the fine tuning of differentiation fates between cells with high effector functions but low proliferative potential and vice versa (56). The extent of memory $T$ cell differentiation can be modulated by rapamycin (57) or metformin (58). In both cases, it is the induction of a metabolic switch from glycolytic oxidation to fatty acid oxidation that increases the number of antigenspecific CD8 T cells in a primary response entering the memory T cell differentiation program. 
However, pharmacological agents have pleiotropic effects. For instance, rapamycin also promotes Tregs and tolerogenic DCs and may inhibit signaling required for costimulatory molecule function. Therefore, it is important to selectively target mTOR modulators to CD8 T cells (59). Additional clinical research will be needed to reveal the entire signaling circuitry for memory $\mathrm{T}$ cell formation and provide the necessary targets for specific components of vaccines to elicit robust long-lived memory $T$ cell responses, with major implications for successful development of vaccines for infectious diseases and cancers. In particular, the status of memory $T$ cell formation and maintenance in conditions of chronic antigen exposure remains poorly characterized. Recent evidence suggests the existence of "exhausted" T cells in chronic infection models that retain substantial in vivo functional potential upon antigen recall (60). In agreement with these experimental observations, the experience in the clinic shows potent antitumor effects upon adoptive transfer of in vitro expanded TILS. The hypothesis that exhausted T cells in tumors and chronic microbial infections are heterogeneous and harbor memory $T$ cells is actively pursued (61).

\section{Immunological fitness of cancer patients}

The patient's immune system's ability to mount potent and durable responses to stimuli, or immunological fitness, is a critical parameter in cancer vaccine development. However, there is no easy definition of immunological fitness. A clear view of "normal" in the human immune system at steady state and in response to challenges at a systems level is still lacking, much less a detailed understanding of global alterations of the human immune system in cancer patients at baseline and upon stimulation. Defining these would be a daunting task, given the considerable heterogeneity of immunological parameters among individuals, which is partly attributable to genetic polymorphisms and in large part associated with environmental exposures, as documented by a study on identical healthy twins (62) and another one in the general population (63).

Cancer patients, particularly those with advanced disease, have signs of major immune abnormalities readily detectable in peripheral blood, such as increased numbers of myeloidderived suppressor cells and regulatory $T$ cells $(64,65)$. Yet, the ability to respond to recall antigens may be variably preserved in many. The possibility that chemotherapy may durably compromise the ability of CD4 T cells to respond has been raised long ago. For example, chemotherapy-treated lung cancer patients had inferior clinical benefit to treatment with PD-L1 blocking antibody relative to chemotherapy-naïve patients (66). Systemic immunomodulation targeting innate immunity (for example by TLR agonists) or adaptive immunity (for example by checkpoint blockade) will likely prove important in improving the immunologic fitness of cancer patients, and could be used at much lower doses in the context of vaccination. Additional interventions may help attenuate cancer-related immune deregulation. For example, low dose cyclophosphamide has been shown to improve response to vaccines, possibly by attenuating Treg or by creating more room in the T cell niche for expansion of antigen-specific clones (67). Similarly, cisplatin synergized with a therapeutic vaccine in a preclinical mouse model of highrisk HPV-induced cancer (68) . Lastly, the effects of commensal and pathogenic microbes, 
especially the intestinal microbiome and chronic infections such as EBV and CMV, on immunological fitness in patients with cancer will have to be addressed to fully capture immune variation in response to vaccines.

Roadmap for the next decade The scientific challenges impeding the development of effective cancer vaccines mirror many of the challenges impeding vaccine development for globally important infectious diseases. These include 1) a lack of understanding at the molecular level of the $B$ and $T$ cell repertoire, also known as the human immunome; 2 ) limited data on the human antigenome, or the antigen(s) required for disease prevention and control; 3) limited understanding of optimal strategies to elicit specific and durable immune responses in humans, in other words the "rules of immunogenicity"; and 4) identifying the optimal means to harness innate immunity.

One of the highest priorities in cancer vaccinology is to define optimal delivery of tumor antigens, in terms of technology, materials, route, and schedule. Such baseline data would greatly change the landscape for cancer vaccinology, and a large multicenter clinical study or series of iterative smaller studies comparing therapeutic vaccination approaches in a dynamic fashion would be highly beneficial and timely. A rapid screening of comparable delivery platforms and materials, antigen doses, adjuvants, schedules of prime and boost technology combinations, frequency of vaccination, and routes of delivery is necessary and can be achieved through clinical studies adopting open-ended adaptive Bayesian designs. Vaccines, unlike other anti-cancer drug classes, can be monitored by easily measurable and relevant pharmacodynamic markers to compare effects among study arms with small cohorts early in the drug development cycle. Even though individual variability in humans is large, cohorts of approximately ten individuals should provide distinct clues as to the relative potency of different vaccines and platforms.

The goal of developing clinically effective cancer vaccines is best attainable through the concerted work of multidisciplinary international consortium teams whose expertise can match the complexity of human vaccinology. The overall strategy of the first steps in clinical testing could immediately build on the few existing shared tumor antigens with a proven record of immunogenicity as well as safety, such as the MAGE-type antigens (NY-ESO-1, MAGE-A1, MAGE-A3 etc.), in carefully defined populations of patients in whom these antigens are highly expressed. Alternatively, one may use well-defined viral antigens for virus-induced cancers, such as the HPV E6 and E7 oncogenic proteins in high-risk HPV16. Vaccination in the adjuvant setting after frontline standard of care therapy resulting in complete responses (usually a combination of surgery, chemotherapy, and radiation) appears to be quite suitable for some arms of such trials, given the number of available patients, the paucity of therapeutic options in this setting, and the likelihood of maximal benefit from adjuvant vaccination in the setting of minimal residual disease. Combinations of vaccines with immunomodulatory approaches such as checkpoint inhibitors as well as chemotherapy should be considered in parallel cohorts of the same study, to rapidly screen multiple approaches and identify those worth retaining for further testing. 
Another priority for accelerating cancer vaccine development is to vaccinate healthy donors with the same vaccines as cancer patients, to compare immune fitness in people with and without cancer. Despite the obvious caveat that only a restricted set of vaccines may be proposed to healthy donors, these comparative studies would benefit from standardized protocols assessing innate and adaptive immunity and a systems immunology analysis of immune responses, including transcriptome, immunome, epigenome, and microbiome analyses. In this regard, the tumor immunology community will need to develop the metrics and define some of the assays to be used. Defining immunological fitness and having appropriate biomarkers for it will be important milestones towards achieving greater success for next-generation cancer vaccines. An important limitation is that most of these metrics can only be systematically applied to circulating immune cells. Whether immune biomarkers in blood can accurately reflect immune responses in tissues including tumors remains to be determined and will be one of the important future tasks.

Multinational collaborative studies can best succeed if harmonized assays can be established across reference laboratories, including a data management/bioinformatics core, which will support the entire consortium. Establishment of cohorts where baseline information on immune repertoire, microbiome, and other factors can be assessed before perturbation by vaccination will be essential. Assays should include deep phenotypic and functional characterization of immune responses along with deep multiparameter serum assays and deep sequencing of $T$ cell and B cell receptors evoked by vaccination. Systems immunology approaches will establish a solid baseline capturing the immune response variables that define a normal immune system and provide a clear view of the range of variation among human individuals. This step is essential for capturing immune variation and defining the baseline immunological fitness in cancer patients.

In parallel, the self peptidome of subsets of individuals from heterogeneous populations with respect to age, gender, geography, and ethnicity will be characterized to enable accurate neoantigen identification and validation. This can be accomplished by integrated deep genomics sequencing and mass spectrometry-based proteomics combined with biochemical validation of HLA binding of candidate peptides and functional validation of their recognition by peripheral blood T cell precursors. This should support a systematic effort at identifying the relevant tumor antigens for cancer vaccines. In this endeavor, the populations of patients who have been responding to immunomodulatory therapies, particularly immune checkpoint blockade, will serve as a resource for the identification of tumor rejection antigens.

\section{Summary and Next Steps}

In summary, the complexity of effective cancer vaccine development necessitates a multidisciplinary concerted international approach to tackle the challenges ahead in a systematic way. The recent discovery of immune checkpoint inhibitors has demonstrated that the immune system can effectively control a wide range of cancers in a subset of patients. Building on these discoveries, and harnessing recent technological advances in genetic and immune monitoring, successful achievement of the Human Vaccines Project's major objective, 
to decode the human immune system, will provide the foundational knowledge to accelerate therapeutic cancer vaccine development into clinically usable powerful therapies. Pilot clinical research studies on the issues described above will be conducted in the near future to pave the way for large, adaptive clinical trials that will be the backbone for numerous successive arms testing variables involved in vaccine optimization and identifying predictive biomarkers. This will entail creating an international consortium of centers, developing the statistical bases for adaptive clinical studies in cancer immunotherapy, establishing centers for harmonization of immune assays, and launching the assessment of immune fitness in cancer patients and normal controls. By complementing ongoing global efforts and closely integrating academic, governmental, pharmaceutical, and biotechnology stakeholders in a flexible large-scale global consortium, this should provide the potential for achieving the next transformative step in conquering cancer: the development of clinically effective vaccines and immunotherapies.

Acknowledgments: The authors thank Sandi Glass for excellent logistics and planning of the workshop and editorial assistance, and Lisa Gieber for assistance with references. This was supported by the Robert Wood Johnson Foundation, and Glaxo Smith Kline. 
Table 1. Related cancer immunotherapy consortium preceding the Project

\begin{tabular}{|c|c|c|c|}
\hline CONSORTIUM & YEAR & Goals & Leader(s) \\
\hline \multirow[t]{2}{*}{ NCl's antigen and agent prioritization } & 2009 & $\begin{array}{l}\text { Develop a well-vetted, priority-ranked list } \\
\text { of cancer vaccine target antigens }\end{array}$ & \\
\hline & & $\begin{array}{l}\text { To test a new prioritization approach } \\
\text { based on an analytic hierarchy process } \\
\text { for dealing with complex decisions }\end{array}$ & $\begin{array}{l}\text { Martin Cheever and } \\
\text { Matrisian }\end{array}$ \\
\hline \multirow[t]{2}{*}{$\begin{array}{l}\text { Human Immunology Project } \\
\text { Consortium, NIAID Division of Allergy, } \\
\text { Immunology and Transplantation }\end{array}$} & 2010 & $\begin{array}{c}\text { Define profiles/signatures/fingerprints of } \\
\text { steady-state and activated human } \\
\text { immune system }\end{array}$ & $\begin{array}{c}10 \text { member steering } \\
\text { committe, chair: Bali } \\
\text { Pulendran }\end{array}$ \\
\hline & $\begin{array}{l}\text { renewed } \\
2015\end{array}$ & $\begin{array}{c}\text { Create centralized knowledge base \& } \\
\text { resources }\end{array}$ & \\
\hline $\begin{array}{l}\text { Cancer Vaccine Collaborative Trials } \\
\text { Network, Ludwig and Cancer } \\
\text { Research Institutes partnership }\end{array}$ & 2001 & $\begin{array}{l}\text { To centrally coordinate immunological } \\
\text { monitoring and immunotherapy trial } \\
\text { design by field-leading experts from more }\end{array}$ & \\
\hline $\begin{array}{l}\text { Cancer Vaccine Consortium, Cancer } \\
\text { Research Institute and Ludwig } \\
\text { Institute for Cancer Research } \\
\text { together with Cancer Vaccine } \\
\text { Consortium program of the Sabin }\end{array}$ & 2008 & $\begin{array}{l}\text { The two programs aim to address the } \\
\text { needs of the immunotherapy community } \\
\text { to accelerate discovery and development, } \\
\text { and facilitate regulatory discussions about } \\
\text { cancer vaccines and other }\end{array}$ & $\begin{array}{c}\text { Jedd Wolchok, Axel } \\
\text { Hoos }\end{array}$ \\
\hline $\begin{array}{l}\text { Association for Cancer } \\
\text { Immunotherapy (CIMT) }\end{array}$ & 2006 & $\begin{array}{c}\text { To enhance the development of innovative } \\
\text { immunotherapeutics to treat cancer }\end{array}$ & $\begin{array}{l}\text { Group of eight } \\
\text { members }\end{array}$ \\
\hline $\begin{array}{l}\text { CVC/CIC/CIP proficiency testing of } \\
\text { immunoassays }\end{array}$ & 2011 & $\begin{array}{c}\text { To promote international cross-laboratory } \\
\text { immunoassay harmonization }\end{array}$ & $\begin{array}{l}\text { CRI and CIMT } \\
\text { leadership }\end{array}$ \\
\hline $\begin{array}{c}\text { Minimal Information About T cell } \\
\text { Assays }\end{array}$ & 2009 & $\begin{array}{l}\text { To achieve consensus on assay } \\
\text { parameters to be reported in scientific } \\
\text { publications, in a systematic manner }\end{array}$ & $\begin{array}{l}\text { International group } \\
\text { of expert tumor } \\
\text { immunologists }\end{array}$ \\
\hline
\end{tabular}




\section{References}

1. S. A. Rosenberg, J. C. Yang, N. P. Restifo, Cancer immunotherapy: moving beyond current vaccines. Nature medicine 10, 909-915 (2004); published online EpubSep (10.1038/nm1100).

2. I. Melero, G. Gaudernack, W. Gerritsen, C. Huber, G. Parmiani, S. Scholl, N. Thatcher, J. Wagstaff, C. Zielinski, I. Faulkner, H. Mellstedt, Therapeutic vaccines for cancer: an overview of clinical trials. Nature reviews. Clinical oncology 11, 509-524 (2014); published online EpubSep (10.1038/nrclinonc.2014.111).

3. J. Obeid, Y. Hu, C. L. Slingluff, Jr., Vaccines, Adjuvants, and Dendritic Cell Activators-Current Status and Future Challenges. Seminars in oncology 42, 549-561 (2015); published online EpubAug (10.1053/j.seminoncol.2015.05.006).

4. J. Pol, N. Bloy, A. Buque, A. Eggermont, I. Cremer, C. Sautes-Fridman, J. Galon, E. Tartour, L. Zitvogel, G. Kroemer, L. Galluzzi, Trial Watch: Peptide-based anticancer vaccines. Oncoimmunology 4, e974411 (2015); published online EpubApr (10.4161/2162402X.2014.974411).

5. D. E. Speiser, P. Romero, Molecularly defined vaccines for cancer immunotherapy, and protective T cell immunity. Seminars in immunology 22, 144-154 (2010); published online EpubJun (10.1016/j.smim.2010.03.004).

6. A. Thomas, G. Giaccone, Why has active immunotherapy not worked in lung cancer? Annals of oncology : official journal of the European Society for Medical Oncology / ESMO 26, 2213-2220 (2015); published online EpubNov (10.1093/annonc/mdv323).

7. C. J. Melief, T. van Hall, R. Arens, F. Ossendorp, S. H. van der Burg, Therapeutic cancer vaccines. The Journal of clinical investigation 125, 3401-3412 (2015); published online EpubSep 1 (10.1172/JCl80009).

8. S. L. Topalian, C. G. Drake, D. M. Pardoll, Immune checkpoint blockade: a common denominator approach to cancer therapy. Cancer cell 27, 450-461 (2015); published online EpubApr 13 (10.1016/j.ccell.2015.03.001).

9. M. M. Gubin, X. Zhang, H. Schuster, E. Caron, J. P. Ward, T. Noguchi, Y. Ivanova, J. Hundal, C. D. Arthur, W. J. Krebber, G. E. Mulder, M. Toebes, M. D. Vesely, S. S. Lam, A. J. Korman, J. P. Allison, G. J. Freeman, A. H. Sharpe, E. L. Pearce, T. N. Schumacher, R. Aebersold, H. G. Rammensee, C. J. Melief, E. R. Mardis, W. E. Gillanders, M. N. Artyomov, R. D. Schreiber, Checkpoint blockade cancer immunotherapy targets tumour-specific mutant antigens. Nature 515, 577-581 (2014); published online EpubNov 27 (10.1038/nature13988).

10. M. Yadav, S. Jhunjhunwala, Q. T. Phung, P. Lupardus, J. Tanguay, S. Bumbaca, C. Franci, T. K. Cheung, J. Fritsche, T. Weinschenk, Z. Modrusan, I. Mellman, J. R. Lill, L. Delamarre, Predicting immunogenic tumour mutations by combining mass spectrometry and exome sequencing. Nature 515, 572-576 (2014); published online EpubNov 27 (10.1038/nature14001).

11. T. F. Gajewski, The Next Hurdle in Cancer Immunotherapy: Overcoming the Non-T-Cell-Inflamed Tumor Microenvironment. Seminars in oncology 42, 663-671 (2015); published online EpubAug (10.1053/j.seminoncol.2015.05.011).

12. G. T. Motz, S. P. Santoro, L. P. Wang, T. Garrabrant, R. R. Lastra, I. S. Hagemann, P. Lal, M. D. Feldman, F. Benencia, G. Coukos, Tumor endothelium FasL establishes a selective immune barrier promoting tolerance in tumors. Nature medicine 20, 607-615 (2014); published online EpubJun (10.1038/nm.3541).

13. T. N. Schumacher, R. D. Schreiber, Neoantigens in cancer immunotherapy. Science 348, 69-74 (2015); published online EpubApr 3 (10.1126/science.aaa4971). 
14. B. Pulendran, Systems vaccinology: probing humanity's diverse immune systems with vaccines. Proceedings of the National Academy of Sciences of the United States of America 111, 1230012306 (2014); published online EpubAug 26 (10.1073/pnas.1400476111).

15. W. C. Koff, D. R. Burton, P. R. Johnson, B. D. Walker, C. R. King, G. J. Nabel, R. Ahmed, M. K. Bhan, S. A. Plotkin, Accelerating next-generation vaccine development for global disease prevention. Science 340, 1232910 (2013); published online EpubMay 31 (10.1126/science.1232910).

16. W. C. Koff, I. D. Gust, S. A. Plotkin, Toward a human vaccines project. Nature immunology 15, 589-592 (2014); published online EpubJul (10.1038/ni.2871).

17. T. Schenkelberg, M. P. Kieny, A. E. Bianco, W. C. Koff, Building the Human Vaccines Project: strategic management recommendations and summary report of the 15-16 July 2014 business workshop. Expert review of vaccines 14, 629-636 (2015); published online EpubMay (10.1586/14760584.2015.1013466).

18. M. A. Neller, J. A. Lopez, C. W. Schmidt, Antigens for cancer immunotherapy. Seminars in immunology 20, 286-295 (2008); published online EpubOct (10.1016/j.smim.2008.09.006).

19. A. M. Eggermont, Therapeutic vaccines in solid tumours: can they be harmful? European journal of cancer 45, 2087-2090 (2009); published online EpubAug (10.1016/j.ejca.2009.05.004).

20. D. L. Morton, N. Mozzillo, J. F. Thompson, M. C. Kelley, M. Faries, J. Wagner, An international randomized, phase III trial of bacillus Calmette-Guerin (BCG) plus allogeneic melanoma vaccine (MCV) or placebo after complete resection of melanoma metastatic to regional or distant sites. $J$ Clin Oncology 25, 8508 (2007).

21. D. Jocham, A. Richter, L. Hoffmann, K. Iwig, D. Fahlenkamp, G. Zakrzewski, E. Schmitt, T. Dannenberg, W. Lehmacher, J. von Wietersheim, C. Doehn, Adjuvant autologous renal tumour cell vaccine and risk of tumour progression in patients with renal-cell carcinoma after radical nephrectomy: phase III, randomised controlled trial. Lancet 363, 594-599 (2004); published online EpubFeb 21 (10.1016/S0140-6736(04)15590-6).

22. P. van der Bruggen, C. Traversari, P. Chomez, C. Lurquin, E. De Plaen, B. Van den Eynde, A. Knuth, T. Boon, A gene encoding an antigen recognized by cytolytic T lymphocytes on a human melanoma. Science 254, 1643-1647 (1991); published online EpubDec 13 (

23. P. G. Coulie, B. J. Van den Eynde, P. van der Bruggen, T. Boon, Tumour antigens recognized by T lymphocytes: at the core of cancer immunotherapy. Nature reviews. Cancer 14, 135-146 (2014); published online EpubFeb (10.1038/nrc3670).

24. U. Sahin, O. Tureci, H. Schmitt, B. Cochlovius, T. Johannes, R. Schmits, F. Stenner, G. Luo, I. Schobert, M. Pfreundschuh, Human neoplasms elicit multiple specific immune responses in the autologous host. Proceedings of the National Academy of Sciences of the United States of America 92, 11810-11813 (1995); published online EpubDec 5 (

25. N. A. Rizvi, M. D. Hellmann, A. Snyder, P. Kvistborg, V. Makarov, J. J. Havel, W. Lee, J. Yuan, P. Wong, T. S. Ho, M. L. Miller, N. Rekhtman, A. L. Moreira, F. Ibrahim, C. Bruggeman, B. Gasmi, R. Zappasodi, Y. Maeda, C. Sander, E. B. Garon, T. Merghoub, J. D. Wolchok, T. N. Schumacher, T. A. Chan, Cancer immunology. Mutational landscape determines sensitivity to PD-1 blockade in non-small cell lung cancer. Science 348, 124-128 (2015); published online EpubApr 3 (10.1126/science.aaa1348).

26. A. Snyder, V. Makarov, T. Merghoub, J. Yuan, J. M. Zaretsky, A. Desrichard, L. A. Walsh, M. A. Postow, P. Wong, T. S. Ho, T. J. Hollmann, C. Bruggeman, K. Kannan, Y. Li, C. Elipenahli, C. Liu, C. T. Harbison, L. Wang, A. Ribas, J. D. Wolchok, T. A. Chan, Genetic basis for clinical response to CTLA-4 blockade in melanoma. The New England journal of medicine 371, 2189-2199 (2014); published online EpubDec 4 (10.1056/NEJMoa1406498). 
27. M. S. Rooney, S. A. Shukla, C. J. Wu, G. Getz, N. Hacohen, Molecular and genetic properties of tumors associated with local immune cytolytic activity. Cell 160, 48-61 (2015); published online EpubJan 15 (10.1016/j.cell.2014.12.033).

28. M. A. Cheever, J. P. Allison, A. S. Ferris, O. J. Finn, B. M. Hastings, T. T. Hecht, I. Mellman, S. A. Prindiville, J. L. Viner, L. M. Weiner, L. M. Matrisian, The prioritization of cancer antigens: a national cancer institute pilot project for the acceleration of translational research. Clinical cancer research : an official journal of the American Association for Cancer Research 15, 53235337 (2009); published online EpubSep 1 (10.1158/1078-0432.CCR-09-0737).

29. B. M. Carreno, V. Magrini, M. Becker-Hapak, S. Kaabinejadian, J. Hundal, A. A. Petti, A. Ly, W. R. Lie, W. H. Hildebrand, E. R. Mardis, G. P. Linette, Cancer immunotherapy. A dendritic cell vaccine increases the breadth and diversity of melanoma neoantigen-specific T cells. Science $\mathbf{3 4 8 , 8 0 3 -}$ 808 (2015); published online EpubMay 15 (10.1126/science.aaa3828).

30. S. Pinto, D. Sommermeyer, C. Michel, S. Wilde, D. Schendel, W. Uckert, T. Blankenstein, B. Kyewski, Misinitiation of intrathymic MART-1 transcription and biased TCR usage explain the high frequency of MART-1-specific T cells. European journal of immunology 44, 2811-2821 (2014); published online EpubSep (10.1002/eji.201444499).

31. P. Romero, D. E. Speiser, N. Rufer, Deciphering the unusual HLA-A2/Melan-A/MART-1-specific TCR repertoire in humans. European journal of immunology 44, 2567-2570 (2014); published online EpubSep (10.1002/eji.201445004).

32. J. Derbinski, S. Pinto, S. Rosch, K. Hexel, B. Kyewski, Promiscuous gene expression patterns in single medullary thymic epithelial cells argue for a stochastic mechanism. Proceedings of the National Academy of Sciences of the United States of America 105, 657-662 (2008); published online EpubJan 15 (10.1073/pnas.0707486105).

33. K. Palucka, J. Banchereau, Cancer immunotherapy via dendritic cells. Nature reviews. Cancer 12, 265-277 (2012); published online EpubApr (10.1038/nrc3258).

34. P. W. Kantoff, T. J. Schuetz, B. A. Blumenstein, L. M. Glode, D. L. Bilhartz, M. Wyand, K. Manson, D. L. Panicali, R. Laus, J. Schlom, W. L. Dahut, P. M. Arlen, J. L. Gulley, W. R. Godfrey, Overall survival analysis of a phase II randomized controlled trial of a Poxviral-based PSA-targeted immunotherapy in metastatic castration-resistant prostate cancer. Journal of clinical oncology: official journal of the American Society of Clinical Oncology 28, 1099-1105 (2010); published online EpubMar 1 (10.1200/JCO.2009.25.0597).

35. J. Rothman, Y. Paterson, Live-attenuated Listeria-based immunotherapy. Expert review of vaccines 12, 493-504 (2013); published online EpubMay (10.1586/erv.13.34).

36. H. L. Kaufman, C. E. Ruby, T. Hughes, C. L. Slingluff, Jr., Current status of granulocytemacrophage colony-stimulating factor in the immunotherapy of melanoma. Journal for immunotherapy of cancer 2, 11 (2014)10.1186/2051-1426-2-11).

37. Y. Brudno, D. J. Mooney, On-demand drug delivery from local depots. Journal of controlled release : official journal of the Controlled Release Society 219, 8-17 (2015); published online EpubDec 10 (10.1016/j.jconrel.2015.09.011).

38. J. T. Schiller, D. R. Lowy, Understanding and learning from the success of prophylactic human papillomavirus vaccines. Nature reviews. Microbiology 10, 681-692 (2012); published online EpubOct (10.1038/nrmicro2872).

39. R. W. Carter, C. Thompson, D. M. Reid, S. Y. Wong, D. F. Tough, Preferential induction of CD4+ T cell responses through in vivo targeting of antigen to dendritic cell-associated C-type lectin-1. Journal of immunology 177, 2276-2284 (2006); published online EpubAug 15 (

40. J. Idoyaga, A. Lubkin, C. Fiorese, M. H. Lahoud, I. Caminschi, Y. Huang, A. Rodriguez, B. E. Clausen, C. G. Park, C. Trumpfheller, R. M. Steinman, Comparable T helper 1 (Th1) and CD8 T-cell immunity by targeting HIV gag p24 to CD8 dendritic cells within antibodies to Langerin, DEC205, 
and Clec9A. Proceedings of the National Academy of Sciences of the United States of America 108, 2384-2389 (2011); published online EpubFeb 8 (10.1073/pnas.1019547108).

41. E. Klechevsky, A. L. Flamar, Y. Cao, J. P. Blanck, M. Liu, A. O'Bar, O. Agouna-Deciat, P. Klucar, L. Thompson-Snipes, S. Zurawski, Y. Reiter, A. K. Palucka, G. Zurawski, J. Banchereau, Cross-priming CD8+ T cells by targeting antigens to human dendritic cells through DCIR. Blood 116, 1685-1697 (2010); published online EpubSep 9 (10.1182/blood-2010-01-264960).

42. D. E. Speiser, D. Lienard, N. Rufer, V. Rubio-Godoy, D. Rimoldi, F. Lejeune, A. M. Krieg, J. C. Cerottini, P. Romero, Rapid and strong human CD8+ T cell responses to vaccination with peptide, IFA, and CpG oligodeoxynucleotide 7909. The Journal of clinical investigation 115, 739746 (2005); published online EpubMar (10.1172/JCl23373).

43. R. Perret, S. R. Sierro, N. K. Botelho, S. Corgnac, A. Donda, P. Romero, Adjuvants that improve the ratio of antigen-specific effector to regulatory $T$ cells enhance tumor immunity. Cancer research 73, 6597-6608 (2013); published online EpubNov 15 (10.1158/0008-5472.CAN-130875).

44. I. Apostolou, $\mathrm{H}$. von Boehmer, In vivo instruction of suppressor commitment in naive $\mathrm{T}$ cells. The Journal of experimental medicine 199, 1401-1408 (2004); published online EpubMay 17 (10.1084/jem.20040249).

45. R. A. Rosalia, E. D. Quakkelaar, A. Redeker, S. Khan, M. Camps, J. W. Drijfhout, A. L. Silva, W. Jiskoot, T. van Hall, P. A. van Veelen, G. Janssen, K. Franken, L. J. Cruz, A. Tromp, J. Oostendorp, S. H. van der Burg, F. Ossendorp, C. J. Melief, Dendritic cells process synthetic long peptides better than whole protein, improving antigen presentation and T-cell activation. European journal of immunology 43, 2554-2565 (2013); published online EpubOct (10.1002/eji.201343324).

46. D. P. Carbone, I. F. Ciernik, M. J. Kelley, M. C. Smith, S. Nadaf, D. Kavanaugh, V. E. Maher, M. Stipanov, D. Contois, B. E. Johnson, C. D. Pendleton, B. Seifert, C. Carter, E. J. Read, J. Greenblatt, L. E. Top, M. I. Kelsey, J. D. Minna, J. A. Berzofsky, Immunization with mutant p53- and K-rasderived peptides in cancer patients: immune response and clinical outcome. Journal of clinical oncology : official journal of the American Society of Clinical Oncology 23, 5099-5107 (2005); published online EpubAug 1 (10.1200/JCO.2005.03.158).

47. G. G. Kenter, M. J. Welters, A. R. Valentijn, M. J. Lowik, D. M. Berends-van der Meer, A. P. Vloon, F. Essahsah, L. M. Fathers, R. Offringa, J. W. Drijfhout, A. R. Wafelman, J. Oostendorp, G. J. Fleuren, S. H. van der Burg, C. J. Melief, Vaccination against HPV-16 oncoproteins for vulvar intraepithelial neoplasia. The New England journal of medicine 361, 1838-1847 (2009); published online EpubNov 5 (10.1056/NEJMoa0810097).

48. J. W. Yewdell, Designing CD8+ T cell vaccines: it's not rocket science (yet). Current opinion in immunology 22, 402-410 (2010); published online EpubJun (10.1016/j.coi.2010.04.002).

49. F. K. Stevenson, A. Mander, L. Chudley, C. H. Ottensmeier, DNA fusion vaccines enter the clinic. Cancer immunology, immunotherapy : CII 60, 1147-1151 (2011); published online EpubAug (10.1007/s00262-011-1042-2).

50. J. A. Williams, Improving DNA vaccine performance through vector design. Current gene therapy 14, 170-189 (2014).

51. C. L. Trimble, M. P. Morrow, K. A. Kraynyak, X. Shen, M. Dallas, J. Yan, L. Edwards, R. L. Parker, L. Denny, M. Giffear, A. S. Brown, K. Marcozzi-Pierce, D. Shah, A. M. Slager, A. J. Sylvester, A. Khan, K. E. Broderick, R. J. Juba, T. A. Herring, J. Boyer, J. Lee, N. Y. Sardesai, D. B. Weiner, M. L. Bagarazzi, Safety, efficacy, and immunogenicity of VGX-3100, a therapeutic synthetic DNA vaccine targeting human papillomavirus 16 and $18 \mathrm{E} 6$ and $\mathrm{E} 7$ proteins for cervical intraepithelial neoplasia 2/3: a randomised, double-blind, placebo-controlled phase $2 \mathrm{~b}$ trial. Lancet,386, 207888 (2015) published online EpubSep 16 (10.1016/S0140-6736(15)00239-1). 
52. U. Sahin, K. Kariko, O. Tureci, mRNA-based therapeutics--developing a new class of drugs. Nature reviews. Drug discovery 13, 759-780 (2014); published online EpubOct (10.1038/nrd4278).

53. H. Kubler, B. Scheel, U. Gnad-Vogt, K. Miller, W. Schultze-Seemann, F. Vom Dorp, G. Parmiani, C. Hampel, S. Wedel, L. Trojan, D. Jocham, T. Maurer, G. Rippin, M. Fotin-Mleczek, F. von der Mulbe, J. Probst, I. Hoerr, K. J. Kallen, T. Lander, A. Stenzl, Self-adjuvanted mRNA vaccination in advanced prostate cancer patients: a first-in-man phase I/Ila study. Journal for immunotherapy of cancer 3, 26 (2015)10.1186/s40425-015-0068-y).

54. S. M. Kaech, W. Cui, Transcriptional control of effector and memory CD8+ T cell differentiation. Nature reviews. Immunology 12, 749-761 (2012); published online EpubNov (10.1038/nri3307).

55. R. R. Rao, Q. Li, M. R. Gubbels Bupp, P. A. Shrikant, Transcription factor Foxo1 represses T-betmediated effector functions and promotes memory CD8(+) T cell differentiation. Immunity 36, 374-387 (2012); published online EpubMar 23 (10.1016/j.immuni.2012.01.015).

56. J. Bottcher, P. A. Knolle, Global transcriptional characterization of CD8+ T cell memory. Seminars in immunology 27, 4-9 (2015); published online EpubFeb (10.1016/j.smim.2015.03.001).

57. K. Araki, A. P. Turner, V. O. Shaffer, S. Gangappa, S. A. Keller, M. F. Bachmann, C. P. Larsen, R. Ahmed, mTOR regulates memory CD8 T-cell differentiation. Nature 460, 108-112 (2009); published online EpubJul 2 (10.1038/nature08155).

58. E. L. Pearce, M. C. Walsh, P. J. Cejas, G. M. Harms, H. Shen, L. S. Wang, R. G. Jones, Y. Choi, Enhancing CD8 T-cell memory by modulating fatty acid metabolism. Nature 460, 103-107 (2009); published online EpubJul 2 (10.1038/nature08097).

59. A. Berezhnoy, I. Castro, A. Levay, T. R. Malek, E. Gilboa, Aptamer-targeted inhibition of mTOR in T cells enhances antitumor immunity. The Journal of clinical investigation 124, 188-197 (2014); published online EpubJan (10.1172/JCI69856).

60. D. T. Utzschneider, A. Legat, S. A. Fuertes Marraco, L. Carrie, I. Luescher, D. E. Speiser, D. Zehn, T cells maintain an exhausted phenotype after antigen withdrawal and population reexpansion. Nature immunology 14, 603-610 (2013); published online EpubJun (10.1038/ni.2606).

61. D. E. Speiser, D. T. Utzschneider, S. G. Oberle, C. Munz, P. Romero, D. Zehn, T cell differentiation in chronic infection and cancer: functional adaptation or exhaustion? Nature reviews.

Immunology 14, 768-774 (2014); published online EpubNov (10.1038/nri3740).

62. P. Brodin, V. Jojic, T. Gao, S. Bhattacharya, C. J. Angel, D. Furman, S. Shen-Orr, C. L. Dekker, G. E. Swan, A. J. Butte, H. T. Maecker, M. M. Davis, Variation in the human immune system is largely driven by non-heritable influences. Cell 160, 37-47 (2015); published online EpubJan 15 (10.1016/j.cell.2014.12.020).

63. D. Duffy, V. Rouilly, V. Libri, M. Hasan, B. Beitz, M. David, A. Urrutia, A. Bisiaux, S. T. Labrie, A. Dubois, I. G. Boneca, C. Delval, S. Thomas, L. Rogge, M. Schmolz, L. Quintana-Murci, M. L. Albert, C. Milieu Interieur, Functional analysis via standardized whole-blood stimulation systems defines the boundaries of a healthy immune response to complex stimuli. Immunity 40, 436-450 (2014); published online EpubMar 20 (10.1016/j.immuni.2014.03.002).

64. G. T. Motz, G. Coukos, Deciphering and reversing tumor immune suppression. Immunity 39, 6173 (2013); published online EpubJul 25 (10.1016/j.immuni.2013.07.005).

65. S. Solito, I. Marigo, L. Pinton, V. Damuzzo, S. Mandruzzato, V. Bronte, Myeloid-derived suppressor cell heterogeneity in human cancers. Annals of the New York Academy of Sciences 1319, 47-65 (2014); published online EpubJun (10.1111/nyas.12469).

66. E. B. Garon, N. A. Rizvi, R. Hui, N. Leighl, A. S. Balmanoukian, J. P. Eder, A. Patnaik, C. Aggarwal, M. Gubens, L. Horn, E. Carcereny, M. J. Ahn, E. Felip, J. S. Lee, M. D. Hellmann, O. Hamid, J. W. Goldman, J. C. Soria, M. Dolled-Filhart, R. Z. Rutledge, J. Zhang, J. K. Lunceford, R. Rangwala, G. M. Lubiniecki, C. Roach, K. Emancipator, L. Gandhi, K.-. Investigators, Pembrolizumab for the 
treatment of non-small-cell lung cancer. The New England journal of medicine 372, 2018-2028 (2015); published online EpubMay 21 (10.1056/NEJMoa1501824).

67. D. T. Le, E. M. Jaffee, Regulatory T-cell modulation using cyclophosphamide in vaccine approaches: a current perspective. Cancer research 72, 3439-3444 (2012); published online EpubJul 15 (10.1158/0008-5472.CAN-11-3912).

68. T. C. van der Sluis, S. van Duikeren, S. Huppelschoten, E. S. Jordanova, E. Beyranvand Nejad, A. Sloots, L. Boon, V. T. Smit, M. J. Welters, F. Ossendorp, B. van de Water, R. Arens, S. H. van der Burg, C. J. Melief, Vaccine-induced tumor necrosis factor-producing T cells synergize with cisplatin to promote tumor cell death. Clinical cancer research : an official journal of the American Association for Cancer Research 21, 781-794 (2015); published online EpubFeb 15 (10.1158/1078-0432.CCR-14-2142). 